\title{
Public Trust in COVID-19 Prevention and Responses Between January and May 2020 in Bangladesh
}

\author{
Edris Alam (iD) 1,2 \\ Khameis Al Abdouli' \\ Amar Hassan Khamis (iD) ${ }^{3}$ \\ Hafiz Uddin Bhuiyan ${ }^{4}$ \\ Kazi Abdur Rahman ${ }^{5}$ \\ 'Faculty of Resilience, Rabdan Academy, \\ Abu Dhabi, United Arab Emirates; \\ ${ }^{2}$ Department of Geography and \\ Environmental Studies, University of \\ Chittagong, Chittagong, 433I, \\ Bangladesh; ${ }^{3} \mathrm{Hamdan}$ Bin Mohammed \\ College of Dental Medicine, Abu Dhabi, \\ United Arab Emirates; ${ }^{4}$ Institute of Social \\ Welfare and Research, University of \\ Dhaka, Dhaka, 1000, Bangladesh; ${ }^{5}$ The \\ Government of the People's Republic \\ Bangladesh, Dhaka, Bangladesh
}

Correspondence: Edris Alam

Email ealam@ra.ac.ae
Background and Aims: Although the Government of Bangladesh (GoB) developed some policy initiatives during the first phase of COVID-19, their efforts were questioned due to indecision, late policy decisions and implementation, and a proliferation of fake testing and fake news. As such, this research aims to examine public trust in preparedness and response measures undertaken by both the GoB and private sector organisations in Bangladesh between January and May 2020.

Methods: A cross-sectional survey method was applied to a sample of Bangladeshi residents using a questionnaire distributed between April and June 2020. Three hundred and seven respondents participated in an online questionnaire that was disseminated on online outlets, such as e-mail, Facebook Messenger, and WhatsApp. The survey questionnaire was distributed to potential respondents, and continuous-chain messages were provided. Data were analyzed using exploratory factor analysis (EFA).

Findings: Of the 307 participants, $77 \%$ were male and 23\% were female. Findings suggest that the participants showed greater approval of private sector responses than of governmental preparedness and response activities. For preparedness activities, participants were negative about both the GoB efforts to organize and provide personal protective equipment (PPE) for doctors in time as a safeguard against COVID-19, and also the lack of coordination and informed decision-making in relation to facing COVID-19. Respondents were asked to share their perception of the suitability of GoB pandemic management plans, as evidenced by plan effectiveness during the COVID-19 pandemic.

Conclusion: A lower level of trust was demonstrated by the Bangladeshis with regard to preparedness and response measures taken in Bangladesh. Based on participants' concerns and suggestions and a review of drawback of policy responses in the early stage, a set of recommendations are provided for future pandemics like public health emergency risk management in Bangladesh.

Keywords: business continuity management, COVID-19, public trust, prevention, response

\section{Introduction}

Novel coronavirus 2 (SARS-CoV-2) has emerged as the largest public health crisis in the world. The pandemic has prevailed over 18 months since its declaration by the World Health Organization (WHO) on 11th March 2020. According to the WHO, as of 1st September, 2021, the COVID-19 has caused over 4 million casualties with more than 217 million people confirmed infected across 223 countries and territories in the world. ${ }^{1}$ The first coronavirus case in Bangladesh was recorded on March 8, 2020, whilst diagnosing passengers returning from Italy, but 
many experts think that some of the COVID-19 cases already had entered the country before this date and had not been detected due to lack of adequate monitoring systems. $^{2}$ The total number of infected COVID-19 cases in Bangladesh on 20 March 2020 was 16, and the number rose to 114 on 07 April 2020. The number of daily infected cases reported was 54 on 08 April 2020 which rose exponentially to over 1054 as of 11 May 2020. Since 28 May 2020, the daily reported new cases of the COVID19 have been over 2000 with an increase to 4008 as of 17 June $2020 .^{3}$ This implies that the COVID-19 new cases are constantly increasing over a five-month period. According to the Government of Bangladesh (GoB), as of 21st April 2021, the number of confirmed infected cases was 727,780 and reported deaths in Bangladesh were 10, 588, respectively. ${ }^{3}$ Institutional responses to COVID-19 were intensified only when the infection cases rose to a peak, which caused a reactive approach from public health disaster management. This implies that the GoB adopted a "wait and see" technique responding to COVID-19, which increased the number of infected cases and deaths. ${ }^{4}$

Bangladesh is a lower-middle-income country ranked the world's eight-most populous country with a population of 160 million and a density of 1265 people per $\mathrm{km}^{2}$. The urban-rural population ratio is $37.4: 62.6$. The per capita income of the country in 2019 is USD $1855.74 \$$, a rank of 139 among 195 countries. $^{5}$ The health expenditure of Gross Domestic Product (GDP) in 2018 was 2.34\%, whereas the global average was $9.85 \%{ }^{6}$ Bangladesh is a de jure representative democracy under its constitution, with a unitary parliamentary republic. However, the country's national parliament is not effectively functional, and bureaucracy is extremely politicized. ${ }^{7}$ Consequently, it has negative implications for the spirit and competence of the public servants as well as for the standard of service delivery. ${ }^{7}$ The country received a score of 2.27 out of 7 in regard to public trust in politicians - a quite low ranking in the world. ${ }^{8}$ According to the Global Health Security (GHS) Index (the GHS Index is a project of the Nuclear Threat Initiative (NTI) and the Johns Hopkins Center for Health Security (JHU)), Bangladesh was placed in 113 among 195 countries on the overall score of prevention, detection, response, health, norms, and risk. Adult (15 and above years old) literacy was $74.4 \%$ in $2019 .{ }^{9}$

Healthcare is acknowledged in the constitution. The $\mathrm{GoB}$ is responsible for governing, financing, and operating the healthcare system. The country enacted an infectious disease (prevention, control and elimination) act in 2018. According to the financial health profile of the World Health Organisation in 2017, the share of revenues for healthcare as a percentage of current expenditure on healthcare from private, public and international counterpart includes $76.55,16.69$ and $6.76 \%$, respectively. ${ }^{10}$ The Ministry of Health and Family Welfare is the central healthcare authority in Bangladesh. The Director General of the Institute of Epidemiology Disease Control and Research (IEDCR) which is the technical body of the Ministry of Health and Family Welfare worked as an official spokesperson for COVID-19 updates and information dissemination. Bangladesh has 64 districts where district hospitals are used for general health and family planning services. According to the World Health Organization's Global Health Workforce Statistics in 2018, the country has 0.581 physicians per 1000 populations. According to the same source in 2016, the country has 0.79 beds per 1000 populations. In March 2020, Bangladesh had only 1169 ICU beds (432 governments and 737 private) which were quite insufficient to tackle multiple outbreaks, especially for a population of 160 million. ${ }^{11}$

The GoB launched early response measures including screening passengers at Dhaka airport from China on 22 January 2020 onward, and suspended the celebration of National Independent day, 26 March 2020. The GoB has undertaken and implemented COVID-19 policy measures, such as stopping prayers at mosques, social isolation, self-isolation, social distancing, quarantine (both designated and at home), remote work processes, lockdown, travel bans, closure of non-essential services, flight closures, and continuous disinfection and sterilization initiatives. On the 16th of March, the government ordered closure of educational institutions to combat the rising case of coronavirus. The GoB allocated a total cost of USD $29,550,000$ million by initiating the National Preparedness and Response Plan (NPRP) for COVID-19 on 18 March 2020. The plan aims to prevent the crossborder entry of COVID-19 disease and to limit transmission in Bangladesh via any source. The funding was channelled through governmental institutions, spent on the preparedness of hospital, surveillance and laboratory diagnosis, and risk communication. ${ }^{12}$ On 23rd of March, the government directed that all public and private sectors be closed from 26 March to 4 April, which was extended several phases later as a modality of flattening the curve of the virus. ${ }^{13}$ Although these policies were undertaken 
and implemented in Bangladesh, there were concerns about inadequate preparedness and response measures undertaken by the government due to indecision, late policy decisions and implementation, withdrawal of lockdown when it was required to halt community transmission, fake testing, and a large quantity of fake news and misinformation. ${ }^{13-15}$ As such, this research aims to understand Bangladeshi residents' trust and confidence in preparedness and response measures undertaken by the GoB and private sectors (ie, banking, shops, supermarket and large shopping centres) between January and May 2020.

\section{Methods and Approaches Participant Selection and Sampling Procedure}

This cross-sectional study was conducted on a sample of resident Bangladeshi communities who are over 18 and above year old. The questionnaire was piloted with ten participants, and comments were considered whilst developing the main questionnaire. The online Google Docs platform was used to construct the questionnaire and generate a survey link that was sent to the potential participants via e-mail, Facebook Messenger, and WhatsApp. In particular, convenience sampling was applied to distribute the questionnaires to participants through online platforms. Social media is used to communicate with many people, and it is mostly unrestricted for communication and debates in Bangladesh. Our online survey form was sent to 410 potential participants, and it was active from 12 April to 11 June 2020. Three hundred and seven participants completed the questionnaire, resulting in $25 \%$ non-response to the questionnaire completion. This also allowed potential respondents to read an invitation letter that describes ethical protocols, research purpose and possible outcomes. Then, they can either complete the questionnaire form or turn down the invitation.

Prior to the data collection, ethical clearance was sought and approved by the University of Chittagong's Ethics Committee for the Department of Geography (Protocol number: CUNI-13/0040). A complete ethics statement was included at the beginning of the questionnaire, which was posted via online sources. No personal identifiers were collected. The participants were coded by their institution and position for anonymity. Thus, the study adheres to national and international standards, particularly the Declaration of Helsinki - ethical principles for research involving human subjects.

\section{Data Collection Procedure}

The data were collected using a self-governed questionnaire that assesses preparedness and response measures and business continuity plans taken by the GoB and private sectors between January and May 2020. The content of the questionnaire was adopted from previously published studies ${ }^{16-18}$ and subjected to a thorough review by public health and social sciences experts. Both quantitative and qualitative methods were utilized in this research to better understand their opinions about measures undertaken by the GoB and private sectors. No approaches are free from limitations. ${ }^{19}$ However, combined methods exacerbate benefits when either qualitative or quantitative approaches are applied separately. ${ }^{20}$ The questionnaire is composed of three main sections. The first section included seven structural questions relating to participants' sociodemographic characteristics, including age, gender, marital status, area of residence, sectors of works, income and education levels. The second section, which contains 23 items, is about participants' trust in preparedness and response measures taken by the GoB. These items are rated on a 5-point Likert scale, ranging from (5) strongly agree to (1) strongly disagree. The third part is composed of 5 items related to the preparedness, response, and business continuity measures taken by private sector authorities in Bangladesh. Participants indicated that their level of trust on a 5-point Likert scale, ranging from (5) strongly agree to (1) strongly disagree. An open-ended question has been embedded in sections 2 and 3 which asked the participants to explain in the event that they were dissatisfied or mistrusted with the GoB and private sectors' activities. In this research, the term "preparedness activity" includes those activities undertaken by the GoB mainly before the pandemic declaration on 11 March 2020 by WHO which is close to the first COVID-19 cases officially announced in Bangladesh on 8 March 2020. The preparedness activities are mainly: immigrant information, screening immigrants arriving from in the airports, quarantine/ separate arrangements/isolation for repatriated Bangladeshis, preparing hospitals, testing arrangements, stockpiles of PPE for doctors and food management and education facilities (through distance/online learning) to deal with the consequences of school closure. Response activities include business continuity and media response 
plans, work from home orders, online meetings, teleprescription and online services provision, etc.

\section{Data Analysis Plan and Procedure}

Data was converted from an Excel sheet into SPSS-25 IBM. Exploratory factor analysis (EFA) was used to validate the survey items for each subscale measuring each variable. ${ }^{21}$ Reliability was checked by Cronbach's alpha values, where a level of $60 \%$ or above was taken to denote strong split-half consistency. ${ }^{22}$ Categorical variables were described by frequency and percentage. The scores for the four principal dimensions were calculated by adding the items within each dimension and then described by the mean and standard deviation (SD). The percentage of the means of the scores was calculated according to the number of items per dimension and scaled according to the Likert scale. The resultant score was checked for normality by using the Shapiro-Wilk test. ${ }^{23}$ To compare the scores by demographic variable category, a Student's $t$-test was used. A P-value of 0.05 was applied as a level of significance for all tests. Responses from open-ended questions have been prepared by frequency tally and presented in hierarchical order as per by their weight value in Box 1.

Despite following best practices and protocols to improve the quality of web-based survey from research design to implementation process, ${ }^{24}$ the limitation of such type of research, particularly non-representative of survey participants and selection of participants by convenient sampling are noted.

\section{Results}

\section{Socio-Demographic Characteristics of the Respondents}

The 307 respondents consisted of $77 \%$ males and $23 \%$ females. Of these respondents, $56.7 \%$ respondents are single and $42.3 \%$ are married. There were about $1 \%$ of the respondents who preferred not to disclose marital information. The respondents' age ranges were categorised as $18-30,31-50$, and $51-65$ years, and the percentage for each group were $64.8 \%, 33.2 \%$, and $2 \%$, respectively. The percentage breakdown of the completion of secondary school certificate (SSC), higher secondary school certificate (HSC), diploma, Bachelor's and Master's degree, and Doctor of Philosophy (PhD) were $0.3 \%, 5.9 \%, 1 \%, 41 \%$,
Box I Challenges of COVID-19 Risk Management in Bangladesh Between January and May 2020

Challenges of COVID-19 Risk Management in Bangladesh

Lack of horizontal coordination among implementing agencies particularly with health ministry

Late response for decision making, identifying cases and implementing policy measures

Lack of coordination between GoB and private sector (specifically BGMEA)

Lack of vertical coordination among implementing agencies

Decision to open the garment industries was irresponsible and suggest lack of coordination by the GoB

Decision making was much centralized without connection to realities in ground

No coordination in relief fund including food relief distribution

Government was not firm about which approach of risk management could work better/Lack of informed decision

Lack of accurate, genuine and timely information sharing to communities

Lack of testing facilities in early stage

Lack of hospital and health service management for COVID-19

Corruption of health sector (one said ethical practice is very poor)

The relevant ministry did not pass information to prime minister

Overall institutional failure for risk management

Misinformation and rumor in the media outlet specially social media platforms

Lack of public knowledge and trust in Governmental efforts

Lack of national framework for pandemic risk management

Lack of monitoring system for medical response and policy implementation

Lockdown measures were not taken following the virus spread in China

National level political consensus was needed for pandemic emergency which did not observe in entire period

Opening shopping mall and garment factory

Clear guidance on phasing of Eid-ul-Fitr and Eid-ul-Adha prayers

(Continued) 
Box I (Continued).

\section{Challenges of COVID-19 Risk Management in Bangladesh}

Private sector are not engaged efficient to serve patient which means lack of control and coordination by GoB

Late quarantine decision

Banks were open throughout the time

Opening shopping mall

Lack of monitoring and coordination between Ministry of health and MoDMR

Table I Demographic Characteristics of Participants

\begin{tabular}{|c|c|}
\hline Items/Characteristics of Participants & Frequency (\%) \\
\hline \multicolumn{2}{|l|}{ Gender } \\
\hline Male & $236(76.9)$ \\
\hline Female & $71(23.1)$ \\
\hline \multicolumn{2}{|l|}{ Marital status } \\
\hline Single & $174(56.7)$ \\
\hline Married & $130(42.3)$ \\
\hline Preferred not to tell & $3(1)$ \\
\hline \multicolumn{2}{|l|}{ Age group } \\
\hline $18-30$ & $199(64.8)$ \\
\hline $31-50$ & $102(33.2)$ \\
\hline $51-65$ & $6(2)$ \\
\hline \multicolumn{2}{|l|}{ Place of living } \\
\hline Dhaka & I 48 (48.2) \\
\hline Chittagong & $118(38.4)$ \\
\hline Khulna & $14(4.6)$ \\
\hline Rajshahi & $11(3.6)$ \\
\hline Mymensingh & $9(2.9)$ \\
\hline Barisal & $4(1.3)$ \\
\hline Sylhet & $3(1.0)$ \\
\hline \multicolumn{2}{|l|}{ Educational level } \\
\hline SSC & I $(0.3)$ \\
\hline HSC & $18(5.9)$ \\
\hline Diploma & $3(1.0)$ \\
\hline Bachelor degree & $126(4 I)$ \\
\hline Master degree & $140(45.6)$ \\
\hline Doctor of Philosophy (PhD) & $19(6.2)$ \\
\hline \multicolumn{2}{|l|}{ Sector of work } \\
\hline Government & $112(36.5)$ \\
\hline Private & $195(63.5)$ \\
\hline
\end{tabular}

$45.6 \%$ and $6.2 \%$, respectively. Of all the respondents, $36.5 \%$ were government employees that included practicing doctors, health officials, civil servants, police, social service workers and the remaining $63.5 \%$ were private sector employees (ie, bankers, insurance officials, industrial officials, etc.), unemployed persons and students. The respondents participated from seven administrative divisions in Bangladesh; Dhaka, Chittagong, Khulna, Rajshahi, Mymensingh, Barisal and Sylhet, and the percentages for each division were $48.2 \%, 38.4 \%, 4.6 \%$, $3.6 \%, 2.9 \%, 1.3 \%$ and $1 \%$, respectively. Table 1 presents information on demographics of the participants'.

\section{Validity and Reliability Analysis}

EFA confirmed the validity and reliability of the survey items (Table 2). The majority of factor loading values were greater than 0.60 indicating that each item was positively correlated to the respective items within the three defined categories: governmental sector preparedness, response effort, and private sector preparedness (Table 2). The sample size was also adequate for all factors as the minimum Kaiser, Meyer, Olkin measure of sampling adequacy $(\mathrm{MSA})^{22}$ value was greater than 0.5 and statistically significant $(\mathrm{P}<0.0001)$ (Table 2). Since Cronbach's Alpha per each item was greater than $60 \%$, factor reliability was also achieved (Table 2). ${ }^{23}$

\section{Trust in Government Sector Preparedness, Response Effort and Private Sector Preparedness}

Participants' perception towards public trust in Covid-19 prevention in Bangladesh was assessed through a questionnaire that investigated three principal components: Government preparedness; Response effort; and Private sector in Bangladesh preparedness, each of which comprised of several items (Table 3). The overall mean score of Government preparedness was 32.15 (7.68) indicating that the respondents' perception ranged from "disagree" to "neutral". The item with the highest score was 4.05 (0.99) for the questionnaire item "In my opinion, there is lack in coordination and decision making in relation to facing COVID-19" which indicated that participants' perception was most commonly "agree", while the item "In my opinion, the government of Bangladesh organized and provided PPE for doctors in time as a safeguard against COVID-19." was scored the minimum 2.52 (1.18) and labelled as "disagree". The overall mean score for 
Table 2 Validity and Reliability of the Instrument by Sectors

\begin{tabular}{|c|c|c|c|}
\hline Items in Each Category & $\begin{array}{l}\text { Factor } \\
\text { Loading }\end{array}$ & $\begin{array}{l}\text { KMO' }^{\mathrm{b}} \& \\
\text { Bartlett }\end{array}$ & $\begin{array}{l}\text { Cronbach's } \\
\text { Alphac }^{c} \text { (\%) }\end{array}$ \\
\hline \multicolumn{4}{|l|}{ Preparedness by GoB: (\% of cumulative variance load 52.65) } \\
\hline $\begin{array}{l}\text { In my opinion, the government of Bangladesh held the information about the immigrants and } \\
\text { database of the immigrants and organized quarantine arrangements for the foreign visitors in time } \\
\text { as a safeguard against Covid-19. }\end{array}$ & 0.53 & $0.886^{\mathrm{d}}$ & 82 \\
\hline $\begin{array}{l}\text { In my opinion, the government of Bangladesh organized home quarantine/separate arrangements/ } \\
\text { isolation for repatriate Bangladeshi in time as a safeguard against COVID-I9. }\end{array}$ & 0.50 & & \\
\hline $\begin{array}{l}\text { In my opinion, the government of Bangladesh organize sterilization of non-passenger's goods/ } \\
\text { product/items that arrived from overseas in time as a safeguard against COVID-19. }\end{array}$ & 0.52 & & \\
\hline $\begin{array}{l}\text { In my opinion, the government of Bangladesh organized countrywide sterilization and disinfection } \\
\text { activities in time as a safeguard against COVID-19. }\end{array}$ & 0.62 & & \\
\hline $\begin{array}{l}\text { In my opinion, the government of Bangladesh organizes testing support for the suspects of Covid- } \\
19 \text { infected patient in time as a safeguard against Covid-19. }\end{array}$ & 0.55 & & \\
\hline $\begin{array}{l}\text { In my opinion, the government of Bangladesh organized and prepared hospitals for affected people } \\
\text { in time as a safeguard against COVID-19. }\end{array}$ & 0.60 & & \\
\hline $\begin{array}{l}\text { In my opinion, the government of Bangladesh organized and provided PPE for doctors in time as } \\
\text { a safeguard against COVID-19. }\end{array}$ & 0.52 & & \\
\hline $\begin{array}{l}\text { In my opinion, the government of Bangladesh organized food and support for the low-income } \\
\text { people in time. }\end{array}$ & 0.63 & & \\
\hline $\begin{array}{l}\text { In my opinion, the government of Bangladesh organized food and support for the middle-income } \\
\text { people and other people who become jobless during COVID-19 pandemic. }\end{array}$ & 0.63 & & \\
\hline In my opinion, there is coordination and decision making exists in relation to facing COVID-I9? & 0.30 & & \\
\hline $\begin{array}{l}\text { In my opinion, the government entities in Bangladesh has organized basic health services, food } \\
\text { management and education facilities (through distance/online learning) to deal with the } \\
\text { consequences of the epidemic diseases such as COVID-19 pandemic. }\end{array}$ & 0.37 & & \\
\hline \multicolumn{4}{|l|}{ Response effort by the GoB: (\% of cumulative variance load 55.92) } \\
\hline $\begin{array}{l}\text { I do believe that all agencies within the government of Bangladesh has prepared response and } \\
\text { business continuity plans to deal with the consequences of epidemic diseases such as COVID-19 } \\
\text { pandemic in time. }\end{array}$ & 0.46 & $0.761^{\mathrm{b}}$ & 69.8 \\
\hline $\begin{array}{l}\text { I trust all the preventive, responsive, and business continuity plans prepared by the different } \\
\text { agencies within the government of Bangladesh will be able to deal with the consequences of } \\
\text { epidemic diseases such as COVID-I9 pandemic in time. }\end{array}$ & 0.64 & & \\
\hline $\begin{array}{l}\text { I think that all the government agencies within the government of Bangladesh has the required } \\
\text { capabilities to deal with the consequences of COVID-19 pandemic and insure the business } \\
\text { continuity through providing services by implementing the business continuity plans. }\end{array}$ & 0.51 & & \\
\hline $\begin{array}{l}\text { I think the agencies within the government of Bangladesh is successful in implementing the media } \\
\text { response plans for risk communication providing accurate and timely information about COVID- } \\
\text { 19. }\end{array}$ & 0.55 & & \\
\hline $\begin{array}{l}\text { In my opinion, a sample was taken from the community to develop the response and business } \\
\text { continuity plans in the various government sectors to insure the suitability of these plans during } \\
\text { epidemic diseases such as COVID-19 pandemic. }\end{array}$ & 0.52 & & \\
\hline
\end{tabular}

(Continued) 
Table 2 (Continued).

\begin{tabular}{|c|c|c|c|}
\hline Items in Each Category & $\begin{array}{l}\text { Factor } \\
\text { Loading }\end{array}$ & $\begin{array}{l}\mathrm{KMO}^{\mathrm{b}} \& \\
\text { Bartlett }\end{array}$ & $\begin{array}{l}\text { Cronbach's } \\
\text { Alpha }^{c}(\%)\end{array}$ \\
\hline $\begin{array}{l}\text { In my opinion, the government entities in Bangladesh have the flexibility to deal with the } \\
\text { consequences of the epidemic diseases such as COVID-19 pandemic. }\end{array}$ & 0.44 & & \\
\hline $\begin{array}{l}\text { In my opinion, the Government of Bangladesh is one of the model countries in dealing with } \\
\text { COVID-19 pandemic and business continuity? }\end{array}$ & 0.60 & & \\
\hline $\begin{array}{l}\text { Do you think that some of the procedures and services (ie, work from home, online meeting, tele- } \\
\text { prescription, online services provision and etc.) provided by the government entities in Bangladesh } \\
\text { to cope with COVID-19 pandemic will be continuing in the future and change government service } \\
\text { delivery mechanism? }\end{array}$ & 0.55 & & \\
\hline \multicolumn{4}{|l|}{ Preparedness of private sector in Bangladesh: (\% of cumulative variance load 69.23 ) } \\
\hline $\begin{array}{l}\text { I do believe that all private organizations in Bangladesh have prepared response and business } \\
\text { continuity plans to deal with the consequences of epidemic diseases such as COVID-I9 pandemic } \\
\text { in time. }\end{array}$ & 0.75 & $0.636^{\mathrm{b}}$ & 60 \\
\hline $\begin{array}{l}\text { I trust all the preventive, responsive, and business continuity plans prepared by the different } \\
\text { private organizations in Bangladesh will be able to deal with the consequences of epidemic } \\
\text { diseases such as COVID-19 pandemic. }\end{array}$ & 0.76 & & \\
\hline $\begin{array}{l}\text { In my opinion, a sample was taken from the community to develop the response and business } \\
\text { continuity plans in the private organizations from various sectors to insure the suitability of these } \\
\text { plans during epidemic diseases such as COVID-19 pandemic. }\end{array}$ & 0.57 & & \\
\hline $\begin{array}{l}\text { In my opinion, the private entities within Bangladesh have the flexibility to deal with the } \\
\text { consequences of the epidemic diseases such as COVID-19 pandemic. }\end{array}$ & 0.69 & & \\
\hline $\begin{array}{l}\text { Do you think that some of the procedures and services (ie, work from home, online meeting, tele- } \\
\text { prescription and online services provision and etc.) provided by the private entities in Bangladesh } \\
\text { to cope with COVID-19 pandemic will be continuing in the future and change private sector } \\
\text { service delivery mechanism? }\end{array}$ & 0.70 & & \\
\hline
\end{tabular}

Notes: ${ }^{\mathrm{b}} \mathrm{KMO}, \mathrm{K}$ aiser-Meyer-Olkin. ${ }^{\mathrm{c}}$ Shows the internal consistency. ${ }^{\mathrm{d}} \mathrm{P}$-value $<0.000 \mathrm{I}$.

response effort was 22.40 (4.82) which indicated that their perceptions ranged from "disagree" to "neutral" with a minimum score for the item "In my opinion, the GoB is one of the model countries in dealing with COVID-19 pandemic and business continuity" 2.24 (1.21) labelled as "disagree" while the item scored the highest perception score of $3.06(0.1 .0)$ and was labelled as "neutral".

In my opinion, a sample was taken from the community to develop the response and business continuity plans in the various government sectors to insure the suitability of these plans during epidemic diseases such as COVID-19 pandemic

Although the majority of the governmental response efforts have been rated "disagree to neutral", the participants answered "neutral to agree" to the question that asked whether some of the procedures and services (ie, work from home, online meeting, tele-prescription, online services provision, etc.) provided by the government entities in Bangladesh to cope with COVID-19 pandemic should continue in the future and change government service delivery mechanisms. Preparedness and response activities of the private sector in Bangladesh ranged as "neutral" with Overall score of mean 15.21 (3.20) (Table 3). The item

Do you think that some of the procedures and services (i.e., work from home, online meeting, tele-prescription and online services provision and etc.) provided by the private entities in Bangladesh to cope with COVID-19 pandemic should continue in the future and change private sector service delivery mechanism?

Ranged from "Neutral to Agree" with score 3.50 (0.99) among the participants. However, preparedness, response and business continuity measures undertaken 
Table 3 Participant's Trust in Government Sector Preparedness, Response Effort and Private Sector Preparedness (N = 307)

\begin{tabular}{|c|c|c|c|}
\hline Individual Items & Mean (SD) & $\%$ Mean & Categories \\
\hline Preparedness by the GoB & $32.15(7.68)$ & 58.45 & Dis - N \\
\hline $\begin{array}{l}\text { In my opinion, the government of Bangladesh held the information about the immigrants and database of } \\
\text { the immigrants and organized quarantine arrangements for the foreign visitors in time as a safeguard } \\
\text { against COVID-19. }\end{array}$ & $2.82(1.21)$ & 56.4 & Dis - N \\
\hline $\begin{array}{l}\text { In my opinion, the government of Bangladesh organized home quarantine/separate arrangements/ } \\
\text { isolation for repatriate Bangladeshi in time as a safeguard against COVID-19. }\end{array}$ & $3.07(1.26)$ & 61.4 & $\mathrm{~N}$ \\
\hline $\begin{array}{l}\text { In my opinion, the government of Bangladesh organize sterilization of non-passenger's goods/product/ } \\
\text { items that arrived from overseas in time as a safeguard against Covid-19. }\end{array}$ & $2.72(1.13)$ & 54.4 & Dis - N \\
\hline $\begin{array}{l}\text { In my opinion, the government of Bangladesh organized countrywide sterilization and disinfection } \\
\text { activities in time as a safeguard against COVID-19. }\end{array}$ & $2.69(1.20)$ & 53.8 & Dis - N \\
\hline $\begin{array}{l}\text { In my opinion, the government of Bangladesh organizes testing support for the suspects of Covid-19 } \\
\text { infected patient in time as a safeguard against COVID-19. }\end{array}$ & $2.82(1.26)$ & 56.4 & Dis - N \\
\hline $\begin{array}{l}\text { In my opinion, the government of Bangladesh organized and prepared hospitals for affected people in } \\
\text { time as a safeguard against Covid-19. }\end{array}$ & $2.79(1.22$ & 55.8 & Dis - N \\
\hline $\begin{array}{l}\text { In my opinion, the government of Bangladesh organized and provided PPE for doctors in time as } \\
\text { a safeguard against COVID-19. }\end{array}$ & $2.52(1.18)$ & 50.4 & Dis - N \\
\hline $\begin{array}{l}\text { In my opinion, the government of Bangladesh organized food and support for the low-income people in } \\
\text { time. }\end{array}$ & $3.27(1.08)$ & 65.4 & $\mathrm{~N}-\mathrm{Ag}$ \\
\hline $\begin{array}{l}\text { In my opinion, the government of Bangladesh organized food and support for the middle-income people } \\
\text { and other people who become jobless during COVID-19 pandemic. }\end{array}$ & $2.55(1.17)$ & 51 & Dis - N \\
\hline In my opinion, there is lack in coordination and decision making exists in relation to facing Covid-19? & $4.05(0.99)$ & 81 & $\mathrm{Ag}$ \\
\hline $\begin{array}{l}\text { In my opinion, the government entities in Bangladesh has organized basic health services, food } \\
\text { management and education facilities (through distance/online learning) to deal with the consequences of } \\
\text { the epidemic diseases such as COVID-19 pandemic. }\end{array}$ & $2.85(1.34)$ & 57 & Dis - N \\
\hline Response effort by the GoB & $22.40(4.82)$ & 56 & Dis - N \\
\hline $\begin{array}{l}\text { I do believe that all agencies within the government of Bangladesh has prepared response and business } \\
\text { continuity plans to deal with the consequences of epidemic diseases such as COVID-19 pandemic in } \\
\text { time. }\end{array}$ & $2.64(1.04)$ & 52.8 & Dis - N \\
\hline $\begin{array}{l}\text { I trust all the preventive, responsive, and business continuity plans prepared by the different agencies } \\
\text { within the government of Bangladesh will be able to deal with the consequences of COVID-19 } \\
\text { pandemic in time. }\end{array}$ & $2.85(1.03)$ & 57 & Dis - N \\
\hline $\begin{array}{l}\text { I think that all the government agencies within the government of Bangladesh has the required } \\
\text { capabilities to deal with the consequences of COVID-19 pandemic and insure the business continuity } \\
\text { through providing services by implementing the business continuity plans. }\end{array}$ & $2.60(1.02)$ & 52 & Dis $-N$ \\
\hline $\begin{array}{l}\text { I think the agencies within the government of Bangladesh is successful in implementing the media } \\
\text { response plans for risk communication providing accurate and timely information about COVID-19. }\end{array}$ & $2.92(1.09)$ & 58.4 & Dis - N \\
\hline $\begin{array}{l}\text { In my opinion, a sample was taken from the community to develop the response and business continuity } \\
\text { plans in the various government sectors to insure the suitability of these plans during epidemic diseases } \\
\text { such as COVID-19 pandemic. }\end{array}$ & $3.06(0.1 .0)$ & 61.2 & $N$ \\
\hline $\begin{array}{l}\text { In my opinion, the government entities in Bangladesh have the flexibility to deal with the consequences } \\
\text { COVID- I9 pandemic. }\end{array}$ & $2.78(1.07)$ & 55.6 & Dis - N \\
\hline
\end{tabular}


Table 3 (Continued).

\begin{tabular}{|c|c|c|c|}
\hline Individual Items & Mean (SD) & $\%$ Mean & Categories \\
\hline $\begin{array}{l}\text { In my opinion, the Government of Bangladesh is one of the model countries in dealing with COVID-I9 } \\
\text { pandemic and business continuity? }\end{array}$ & $2.24(1.21)$ & 44.8 & Dis \\
\hline $\begin{array}{l}\text { Do you think that some of the procedures and services (ie, work from home, online meeting, tele-prescription, } \\
\text { online services provision and etc.) provided by the government entities in Bangladesh to cope with COVID-I9 } \\
\text { pandemic will be continuing in the future and change government service delivery mechanism? }\end{array}$ & $2.94(1.05)$ & 66.4 & $\mathrm{~N}-\mathrm{Ag}$ \\
\hline Activities by private sectors in Bangladesh & $|5.2|(3.20)$ & 60.84 & $\mathrm{~N}$ \\
\hline $\begin{array}{l}\text { I do believe that all private organizations in Bangladesh have prepared response and business continuity } \\
\text { plans to deal with the consequences of epidemic diseases such as COVID-19 pandemic in time. }\end{array}$ & $2.8(1.08)$ & 56 & Dis - $N$ \\
\hline $\begin{array}{l}\text { I trust all the preventive, responsive, and business continuity plans prepared by the different private } \\
\text { organizations in Bangladesh will be able to deal with the consequences of epidemic diseases such as } \\
\text { COVID- I } 9 \text { pandemic. }\end{array}$ & $2.94(1.05)$ & 58.8 & Dis - N \\
\hline $\begin{array}{l}\text { In my opinion, a sample was taken from the community to develop the response and business continuity } \\
\text { plans in the private organizations from various sectors to insure the suitability of these plans during } \\
\text { epidemic diseases such as COVID-19 pandemic. }\end{array}$ & $3.03(0.96)$ & 60.6 & $\mathrm{~N}$ \\
\hline $\begin{array}{l}\text { In my opinion, the private entities within Bangladesh have the flexibility to deal with the consequences } \\
\text { of the epidemic diseases such as COVID-19 pandemic. }\end{array}$ & $2.93(1.07)$ & 58.6 & Dis - N \\
\hline $\begin{array}{l}\text { Do you think that some of the procedures and services (ie, work from home, online meeting, tele- } \\
\text { prescription and online services provision and etc.) provided by the private entities in Bangladesh to } \\
\text { cope with COVID-19 pandemic will be continuing in the future and change private sector service } \\
\text { delivery mechanism? }\end{array}$ & $3.50(0.99)$ & 70 & $\mathrm{~N}-\mathrm{Ag}$ \\
\hline
\end{tabular}

Table 4 Appraising of Demographical Factors by Government Preparedness, Response Effort and Private Sector Preparedness in Bangladesh

\begin{tabular}{|l|l|l|l|l|}
\hline Variables & Categories & Government Preparedness & Response Effort & Private Sector Preparedness in Bangladesh \\
\hline Gender & Male & $31.367(7.30)$ & $22.28(4.80)$ & $15.22(3.1 \mathrm{I})$ \\
& Female & $34.75(8.37)$ & $22.83(4.9 \mathrm{I})$ & $\mathrm{I} .18(3.52)$ \\
& P-value & 0.002 & 0.579 & 0.896 \\
\hline \multirow{2}{*}{ Official married } & Single & $33.03(7.28)$ & $22.5 \mathrm{I}(4.75)$ & $15.57(3.08)$ \\
& Official married & $30.99(8.05)$ & $22.27(4.93)$ & $14.74(3.3 \mathrm{I})$ \\
& P-value & 0.017 & 0.694 & $0.01 \mathrm{I}$ \\
\hline \multirow{2}{*}{ Education } & MSc. and plus & $31.44(7.88)$ & $22.1(4.65)$ & $14.82(3.24)$ \\
& BSc. and less & $32.91(7.40$ & $22.73(4.99)$ & $15.63(3.2 \mathrm{I})$ \\
& P-value & 0.048 & 0.194 & 0.009 \\
\hline \multirow{2}{*}{ Age } & $\leq 30$ & $32.84(7.69)$ & $22.46(4.86)$ & $15.5 \mathrm{I}(3.14)$ \\
& $>30$ & $30.83(7.5 \mathrm{I})$ & $22.29(4.76 \mathrm{I})$ & $14.64(3.26)$ \\
& P-value & 0.022 & 0.878 & 0.014 \\
\hline \multirow{2}{*}{ Place of residence } & Dhaka & $31.89(7.98)$ & $22.23(5.03)$ & $14.77(3.42 \mathrm{I})$ \\
& Chattragram & $31.36(7.02 \mathrm{I})$ & $21.84(4.62)$ & $15.4 \mathrm{I}(3.0)$ \\
& Others & $35.37(7.26)$ & $24.66(4.01)$ & $16.02(2.77)$ \\
& P-value & 0.016 & 0.003 & 0.062 \\
\hline
\end{tabular}


by the private sector were markedly rated "Neutral to Disagree".

\section{Appraising of Demographical Factors by Government Preparedness, Response Effort and Private Sector Preparedness in Bangladesh}

The perception of the mean score of government preparedness was a little higher among females at 34.75 (8.37) compared with the mean score among male respondents of 31.367 (7.30) with $P=0.002$ (Table 4). For the other two components, response effort and private sector in Bangladesh, preparedness was similar for male and female respondents; gender was not statistically significant $(\mathrm{P}>$ 0.05). For participants, the perception score was higher in married compared to single respondents. For the component of government preparedness, a comparison between married participants and single participants yielded a score of 33.03 (7.28) and 30.99 (8.05), respectively (p-value was 0.017 ). The same result was found for private sector preparedness in Bangladesh. The score among singles was 15.57 (3.08), while it was 14.74 (3.31) among married participants with a p-value of 0.011 . For educational level, the participants with an education-level attainment of a bachelor's degree or below had significantly higher scores of perception on components of government preparedness and private sector preparedness in Bangladesh compared with participants with an education-level attainment of a master's degree or higher ( $\mathrm{p}$-values were 0.048 and 0.009 , respectively). Younger age groups scored higher (more favourable) the GoB and private sector preparedness in Bangladesh compared to the participants of age group more than 30 years old ( $p$-values were 0.022 and 0.014 respectively).

\section{Discussion}

In this research, public trust refers to community members' confidence that preparedness and response measures undertaken by the government and private sectors against the COVID-19 outbreak could contain the virus outbreak and might serve people's best interests. A study in the Republic of Congo during the 2018 Ebola outbreak showed that low trust in the authorities' ability to deliver public services could prevent people from undertaking precautionary measures during outbreaks, as well as decreasing the acceptance of Ebola vaccines in the public view. ${ }^{25}$ During COVID-19 preparedness and response activities in Nigeria, mistrust in politics undermined public cooperation and compliance with government protocols aimed at limiting the spread of the virus. ${ }^{26}$ On the contrary, higher political trust is associated with compliance with the COVID-19 containment policies. ${ }^{27,28}$ Our quantitative analysis of public responses to government preparedness and response activities are consistently negatively evaluated. The findings of this research are supported by Islam et al, ${ }^{29}$ and Monjur and Hassan, ${ }^{30}$ who also studied the early phase of COVID-19 risk management in Bangladesh. In an answer to an open-ended qualitative narrative regarding the reasons why the public had a lack of trust and deficiencies towards the GoB preparedness and response measures in Bangladesh, 180 participants responded. By the order of frequency of responses, these include: lack of horizontal coordination among implementing agencies particularly with health ministry, late response for decision-making, identifying cases and implementing policy measures, lack of coordination between GoB and private sector, decision to open the garment industries, and lack of accurate, genuine and timely information sharing to communities (Box 1). Participants cited comments that downplayed the threat of the virus that were made by the top political leader in March 2020, when the ruling party's secretary general stated "the ruling party is stronger than coronavirus". 31 This type of commentary published in the leading daily newspaper triggered mistrust in government initiatives and responsibilities in containing the virus.

In a study conducted by Dolitzsch ${ }^{32}$ in 45 countries to measure how the public judge their government efforts in fighting COVID-19, almost $43 \%$ of the study participants stated that their governments are doing too little to respond to the COVID-19 outbreak. In Bangladesh, although the government had taken various measures to control the pandemic such as diagnosis of suspected cases, isolation of infected people, general lockdown, granting general leave from all offices and social distancing, these efforts had minimal impact because of their delayed start and relaxed implementation. ${ }^{33}$ Such negative perception resulted in a lack of public confidence in the policies and response plans implemented by the government. In Singapore, the general public were more confident in the government efforts to contain the COVID-19 pandemic compared with the public confidence during SARS virus in 2002-2003. ${ }^{34}$ Having public confidence in the governmental efforts to contain the spread of the virus will 
facilitate the process of utilizing vaccines when they become available.

The GoB received international attention for its ability to reduce the number of deaths per year from frequently occurring natural hazards with the exception to sudden onset of earthquake and landslide disasters. ${ }^{35}$ The formulation of disaster management policies, rules and acts and establishments of institutions at national and local levels implies that the country has achieved Sendai's Target for the period of $2015-2020 .^{35}$ At the same time, the weaknesses identified by the participants of this research in regard to coordinating the implementation of COVID-19 related physical distancing policies, which are a cause of concern. At the same time, these concerns are also true opportunities to improve governance at all levels. Coordination among service delivery agencies has increasingly become a meaningful way to address complex societal issues. However, it is increasingly challenging to maintain multi-agency coordination in complex and dynamic emergency response scenarios. $^{36}$ Despite Bangladesh having a regulated institutional framework that functions well vertically, the functionality of such systems during COVID-19 pandemic risk management posed a great question. The concern raised by the participants indicates that horizontal collaborations are needed to implement a successful all hazard risk governance. Similar suggestions from another recent research ${ }^{35}$ asserted that despite Bangladeshi disaster response departments and agencies have solid disaster response and recovery experiences, there are further scopes of shared decision-making in planning, information sharing, in resource sharing, communication, collaboration between state and non-state actors and in implementing disaster risk management strategies in an integrated and transparent way.

During the early phase of COVID-19 in 2020, the countries around the world tried to control misinformation and rumour about the virus. A study conducted by the University of Oxford revealed that $33 \%$ social media users in the United States, Argentina, Germany, South Korea, Spain and the United Kingdom had seen false or misleading information about coronavirus. ${ }^{37}$ During that time, misinformation functioned as a meta-risk that diverted public attention from the real origins and risks of the virus. ${ }^{38}$ The absence of accurate information about COVID-19 resulted in inaccurate self-medication in Uganda. $^{39}$ Furthermore, the consequences of panicking from COVID-19 extended to business including the stock market, and foreign trade, and increased the price of essentials, such as surgical masks and face masks, sanitizers, electronics, and electrical materials. ${ }^{40}$ In Bangladesh, lack of coordination among government authorities resulted in miscommunication and misunderstanding of the measures that have been taken by the government. ${ }^{13}$ In contrast with other countries such as Taiwan, the Central Epidemic Command Center (CECC) adopted open and transparent processes to manage the pandemic between government authorities and among general public, which enhanced the public confidence in the government efforts to contain the pandemic. ${ }^{28}$ Developing and implementing an appropriate response communication plan is a critical factor in successfully managing emergencies, which in turn will raise public confidence in government efforts. The failure of Bangladeshi Ministries of Health and Family Welfare, and Information in understanding the population's healthcare need during the time of COVID-19 resulted in miscommunication of protective measures, as well as increasing rumours on social media. ${ }^{33}$ All the above mentioned challenges led to a lack of public confidence in government efforts around implementing COVID-19 physical distancing policies and the acceptance of vaccines when it became available.

\section{Conclusions and Recommendations}

Trust in governments is an important determinant of citizens' compliance with the newly enforced physical distancing policies in a dynamic and changing scenario of crisis. However, the GoB has implemented several disaster risk strategy, act, policy and plans since 1997 and has highly institutionalised and professionalised disaster risk management institutions from central to local service delivery level. The findings suggest that governmental efforts were inadequate in crisis cognition, decision-making, organising testing facilities, implementing social distancing policies, preparing hospitals, business continuity management and coordinating between government service delivery organisations and private sectors. Our qualitative data present that irresponsible commentary about the virus as well as inadequate healthcare facilities both contributed to mistrust about the GoB efforts in COVID-19 risk management. Irrespective of gender, age and place of residence, the participants showed higher trust in private sectors. Based on our above discussion and participants' concerns and suggestions, the following recommendations should be made for future COVID-19 like public health emergency risk management in Bangladesh:

First, a National Pandemic Risk Management Framework should be developed incorporating all public 
and private sectors, non-governmental organizations, and community-based organizations. Like the depth and breadth of experience that the Ministry of Disaster Management and Relief has in tropical cyclone and flood risk management, the capacity and professionalism of the Ministry of Health and Family Welfare needs to be enhanced for pandemic risk management.

Second, there was further scope to show cognition of risk from national leadership that resulted in late decisionmaking about developing preparedness and response in the country. The participants were mainly concerned about late decision-making for lockdown (Table 3 and Box 1), quarantine, isolation, separating COVID-19 positive cases, and implementing social distancing policies. Strength and weakness of these risk reduction strategy implementations should be further identified for future pandemic risk management.

Third, the participants expressed great concern over implementing agencies' lack of coordination between the GoB and private sector, specifically the decision to open the garment industries; poor female workers were to visit factories on a daily basis via mass transport facilities. Additionally, the fact that physical banking facilities and non-essential commercial stores, such as large shopping complexes, were left open, while the GoB closed educational facilities and public sector offices from March 2020 onward raised several concerns. These decisions reduced public trust in the government's decision and heightened concerns about equality of welfare for all sector employees. An equal welfare approach might effectively promote citizen participation, and engender public support for implementing physical distancing policies.

Fourth, the public were extremely confused due to the lack of accurate, genuine and timely information and spread of misinformation and rumor via different online platforms. Therefore, developing clear, precise, consistent and scientific information about the virus and disseminating this through national health spokespersons, political leaders, and government representatives in district and sub-district administrations to the whole community might reduce misinformation and rumor.

\section{Acknowledgments}

The authors would like to thank the study's participants without whom the project would not have been possible. The authors thank the volunteers of the Disaster Action and Development Organisation (DADO) for supporting data collection in Bangladesh. The assistance received by the Disaster Action and Development Organisation (DADO) is broadly acknowledged and indebted. The authors also thank Basma Bent Omar Allagui and Lisa Ann Fraser from Rabdan Academy for conducting a language check, which is much appreciated. The authors gratefully acknowledge generous philanthropic support from the Office of the Vice President of the Rabdan Academy, The United Arab Emirates (UAE).

\section{Author Contributions}

All authors made a significant contribution to the work reported, whether that is in the conception, study design, execution, acquisition of data, analysis and interpretation, or in all these areas; took part in drafting, revising or critically reviewing the article; gave final approval of the version to be published; have agreed on the journal to which the article has been submitted; and agree to be accountable for all aspects of the work.

\section{Disclosure}

The authors report no conflicts of interest in this work.

\section{References}

1. World Health Organization. WHO Coronavirus (COVID-19) Dashboard. Secondary WHO Coronavirus (COVID-19) Dashboard; 2021. Available from: https://covid19.who.int/. Accessed October 19, 2021.

2. Anwar S, Nasrullah M, Hosen MJ. COVID-19 and Bangladesh: challenges and how to address them. Front Public Health. 2020;8 (154). doi:10.3389/fpubh.2020.00154.

3. GoB. COVID-19 situation related health bulletin. Secondary COVID-19 situation related health bulletin; 2021. Available from: https://dghs.gov.bd/index.php/bd/component/content/article?layout= edit\&id=5612. Accessed October 19, 2021.

4. Alam MA. Leading in the shadows: understanding administrative leadership in the context of COVID-19 pandemic management in Bangladesh. Int $J$ Public Leadersh. 2021;17(1):95-107. doi:10.1108/IJPL-06-2020-0050.

5. World Bank. GDP per capita: Bangladesh. Secondary GDP Per Capita. Bangladesh; 2019. Available from: https://data.worldbank. org/indicator/NY.GDP.PCAP.CD?locations=BD. Accessed March 3, 2021.

6. World Bank. Current health expenditure (\% of GDP). Secondary Current health expenditure ( $\%$ of GDP); 2018. Available from: https://data.worldbank.org/indicator/SH.XPD.CHEX.GD.ZS. Accessed March 3, 2021.

7. Khan MM, Islam MS. Democracy and good governance in Bangladesh: are they compatible? Millennial Asia. 2014;5(1):23-40. doi: $10.1177 / 0976399613518855$.

8. World Bank. Trust in government. Secondary Trust in Government. Available from: https://govdata360.worldbank.org/subtopics/ h21 acc114? country=BGD. Accessed March 3, 2021.

9. UNESCO. Education and literacy: Bangladesh. Secondary Education and literacy. Bangladesh; 2019. Available from: http://uis.unesco.org/ en/country/bd. Accessed March 3, 2021.

10. World Health Organization. Health financing profile 2017: Bangladesh. Secondary Health financing profile 2017: Bangladesh. Geneva: World Health Organization (WHO); 2017. Available from: file://C:/Users/edris/AppData/Local/Temp/BAN_HFP.pdf. Accessed March 3, 2021. 
11. Biswas RK, Huq S, Afiaz A, Khan HTA. A systematic assessment on COVID-19 preparedness and transition strategy in Bangladesh. J Eval Clin Pract. 2020;26(6):1599-1611. doi:10.1111/jep.13467

12. GoB. National Preparedness and Response Plan for COVID-19, Bangladesh. Dhaka: Directorate General of Health Services, Ministry of Health and Family Welfare; 2020:46.

13. Shammi M, Bodrud-Doza M, Islam ARMT, Rahman MM. Strategic assessment of COVID-19 pandemic in Bangladesh: comparative lockdown scenario analysis, public perception, and management for sustainability. Environ, Develop Sustainability. 2021;23(4):61 48-6191. doi:10.1007/s10668-020-00867-y

14. Aziz A, Islam MM, Zakaria M. COVID-19 exposes digital divide, social stigma, and information crisis in Bangladesh. Media Asia. 2020;47(3-4):144-151. doi:10.1080/01296612.2020.1843219

15. Cousins S. Bangladesh's COVID-19 testing criticised. Lancet. 2020;396(10251):591. doi:10.1016/S0140-6736(20)31819-5

16. Almutairi AF, BaniMustafa A, Alessa YM, Almutairi SB, Almaleh,Y. Public trust and compliance with the precautionary measures against COVID-19 employed by authorities in Saudi Arabia. Risk Manage Health Care Policy. 2020;13:753-760. doi:10.2147/RMHP.S257287

17. Blair RA, Morse BS, Tsai LL. Public health and public trust: survey evidence from the Ebola Virus Disease epidemic in Liberia. Soc Sci Med. 2017;172:89-97. doi:10.1016/j.socscimed.2016.11.016

18. Wei -H-H, Sim T, Han Z. Confidence in authorities, neighborhood cohesion and natural hazards preparedness in Taiwan. Int J Disaster Risk Reduct. 2019;40:101265. doi:10.1016/j.ijdrr.2019.101265

19. Gregory D, Johnston R, Pratt G, Watts MJ, Whatmore S, editors. The Dictionary of Human Geography. West Sussex: Wiley-Blackwell; 2009.

20. Creswell JW. Research Design: Qualitative, Quantitative, and Mixed Methods Approaches. London:: Sage; 2009.

21. Izquierdo I, Olea J, Abad FJ. Exploratory factor analysis in validation studies: uses and recommendations. Psicothema. 2014;26 (3):395-400. doi:10.7334/psicothema2013.349

22. Cerny BA, Kaiser HF. A study of a measure of sampling adequacy for factor-analytic correlation matrices. Multivariate Behav Res. 1977;12(1):43-47. doi:10.1207/s15327906mbr1201_3

23. Ghasemi A, Zahediasl S. Normality tests for statistical analysis: a guide for non-statisticians. Int $J$ Endocrinol Metab. 2012;10 (2):486-489. doi:10.5812/ijem.3505

24. Eysenbach G. Improving the quality of web surveys: the Checklist for Reporting Results of Internet E-Surveys (CHERRIES). J Med Internet Res. 2004;6(3):e34. doi:10.2196/jmir.6.3.e34

25. Vinck P, Pham PN, Bindu KK, Bedford J, Nilles EJ. Institutional trust and misinformation in the response to the 2018-19 Ebola outbreak in North Kivu, DR Congo: a population-based survey. Lancet Infect Dis. 2019;19(5):529-536. doi:10.1016/S1473-3099(19)30063-5
26. Ezeibe CC, Ilo C, Ezeibe EN, et al. Political distrust and the spread of COVID-19 in Nigeria. Glob Public Health. 2020;15(12):1753-1766. doi:10.1080/17441692.2020.1828987

27. Bargain O, Aminjonov U. Trust and compliance to public health policies in times of COVID-19. J Public Econ. 2020;192:104316. doi:10.1016/j.jpubeco.2020.104316

28. Moon MJ. Fighting COVID-19 with agility, transparency, and participation: wicked policy problems and new governance challenges. Public Adm Rev. 2020;80(4):651-656. doi:10.1111/puar.13214

29. Islam MT, Talukder AK, Siddiqui MN, Islam T. Tackling the COVID-19 pandemic: the Bangladesh perspective. J Public Health Res. 2020;9(4):1794-1894. doi:10.4081/jphr.2020.1794

30. Monjur MR, Hassan MZ. Early phases of COVID-19 management in a low-income country: Bangladesh. Infect Control Hosp Epidemiol. 2020;41(9):1116-1117. doi:10.1017/ice.2020.147

31. Anon. We are stronger than coronavirus, says Quader. The Asian Age; 2020:1.

32. Dölitzsch C. Global study about COVID-19: Dalia assesses how the world ranks their governments' response to the pandemic. Dalia Report; 2020.

33. Islam MD, Siddika A. COVID-19 and Bangladesh: a study of the public perception on the measures taken by the government. EdArXiv. 2020. doi:10.13140/RG.2.2.30042.49608

34. Wong CML, Jensen O. The paradox of trust: perceived risk and public compliance during the COVID-19 pandemic in Singapore. $J$ Risk Res. 2020;23(7-8):1021-1030. doi:10.1080/13669877.20 20.1756386

35. Alam E, Ray-Bennett NS. Disaster risk governance for district-level landslide risk management in Bangladesh. Int J Disaster Risk Reduct. 2021;59:102220. doi:10.1016/j.ijdrr.2021.102220

36. Curnin S, Owen C, Paton D, Brooks B. A theoretical framework for negotiating the path of emergency management multi-agency coordination. Appl Ergon. 2015;47:300-307. doi:10.1016/j.apergo. 2014.10.014

37. Suciu P. COVID-19 misinformation remains difficult to stop on social media. Forbes. 2020;17(April):2020.

38. Krause NM, Freiling I, Beets B, Brossard D. Fact-checking as risk communication: the multi-layered risk of misinformation in times of COVID-19. J Risk Res. 2020;23(7-8):1052-1059. doi:10.1080/ 13669877.2020.1756385

39. Dare SS, Eze ED, Isaac E, et al. COVID-19 pandemic and behavioural response to self-medication practice in Western Uganda. medRxiv. 2021. doi:10.1101/2021.01.02.20248576

40. Alam MS, Alam MZ, Nazir KHMNH, Bhuiyan MAB. The emergence of novel coronavirus disease (COVID-19) in Bangladesh: present status, challenges, and future management. J Adv Vet Anim Res. 2020;7(2):198-208. doi:10.5455/javar.2020.g410
Risk Management and Healthcare Policy

\section{Publish your work in this journal}

Risk Management and Healthcare Policy is an international, peerreviewed, open access journal focusing on all aspects of public health, policy, and preventative measures to promote good health and improve morbidity and mortality in the population. The journal welcomes submitted papers covering original research, basic science, clinical \& epidemiological studies, reviews and evaluations, guidelines, expert opinion and commentary, case reports and extended reports. The manuscript management system is completely online and includes a very quick and fair peer-review system, which is all easy to use. Visit http://www.dovepress.com/testimonials.php to read real quotes from published authors. 